\title{
TPSB2 Gene
}

National Cancer Institute

\section{Source}

National Cancer Institute. TPSB2 Gene. NCI Thesaurus. Code C124246.

This gene is involved in mast cell granule proteolytic activity. 